\title{
Zvláštní kniha o tzv. sovětském románu
}

\author{
Ivo Pospíšil
}

Katerina Clarková: Sovětský román. Dějiny jako rituál. Přel. Vít Schmarc. Praha: Academia, 2015. 411 s. ISBN 978-80-200-2403-9.

Ty tam jsou časy, kdy Roman Jakobson, René Wellek nebo i další jezdili do USA, kde učili americké začátečníky slavistice včetně rusistiky. Nyní je tomu naopak: je to dáno situací, která začala za studené války a vrcholila po rozpadu SSSR. Nejprve byl SSSR zemí nepřítele a bylo třeba jej zkoumat v rámci area studies, částečně i jeho spojence. Od sedmdesátých let 20. století a v kulminačním období po roce 1991 se západní Evropa a USA plní desítkami a stovkami sovětských spisovatelů a literárních kritiků a vědců, zvláště po aféře almanachu Metropol a v době masového exodu židovských občanů SSSR do Izraele a potom dál, většinou znovu do USA, kteří se často živí na amerických univerzitách jako učitelé creative writing nebo přednášejí o ruské literatuře. Byl by asi třeba toto období studovat zblízka v místě, kde se tyto procesy odehrávaly, nebot znamenaly velkou podporu Russian studies, ale současně sem vnesly některé rysy, jež - propojeny s domácími zvyklostmi - zanechaly na severoamerické rusistice trvalé stopy - kvalitativně jí prospěly, ale také jí jistým konjunkturalismem a místy diletantismem uškodily. At̉ tak či onak, přímý dotek Ruska a ruské reality vedl dočasně k mediálnímu vzestupu role americké slavistiky a rusistiky v světovém měřítku. Pro naše politická místa to však znamenalo a dosud znamená nutnost se od Američanů učit i slavistice a rusistice, nebot’ oni jsou reálnými atributy kvality více než v zemi, kde se rusky běžně mluví a píše - recipročně si to lze představit jen stěží. Dokladem toho je české oficiální hodnocení vědeckých výstupů v tzv. RIV. Často se tak stává, že naše nejlepší slavistické a balkanistické studie publikované v slovanských zemích jsou trvale hodnoceny bodovým ziskem nula, nebot nejsou „evropské“ ani „americké“, tedy vznikají jakoby mimo civilizaci. Literární věda se dnes postupně vzdaluje vlastnímu předmětu svého zkoumání, tedy literárnímu artefaktu, a představuje potom podivnou změt kultury a politiky, jež již dávno překročila hranice tradičních areálových studií. Zahraniční studie tohoto typu se k nám překládají jako vzorové a pravda je, že mají u nás zdatné následovníky a konkurenty pěstující novodobý žurnalismus s politickými údaji převzatými z různých zdrojů, také mediálně prosazované a z důvodů lehkého recipování čtenáři také týmiž médii ideologicky ceněné. Přítomná kniha k takovým dílům ve všech složkách zcela nepatří, i když povrchní politizování a žurnalistickou razanci nezapře. Co je však nejproblematičtější: málo se dovídáme o literatuře, tedy v daném případě o tzv. sovětském románu, jako druhu umění. Většinou se soustředí na věci mimoliterární povahy, resp. na řízení literatury z politických míst, i když literatura i v silném ideologickém a cenzurním tlaku si do značné míry uchovává svou autonomii.

Autorka, profesorka srovnávací literatury a slovanských jazyků a literatur (takové znalosti však v knize neprojevuje), dělí svoji knihu na čtyři rozsáhlé kapitoly, které sledují vývoj tzv. socialistického realismu. Její bádání se soustředuje na to, co je blízké historikům a politologům, tedy na určení tohoto směru "shora“, tedy z př́kazu politických míst, stranických orgánů nebo ideologických spisovatelských grémií. To, co napovídá autorčin žurnalismus a publicističnost, které s sebou nesou hrubozrnnost postupů a schematičnost, jsou již její pojetí terminologie. Literatura je klasifikována jen podle politických modelů, a to i tam, kde se mluví o rituálech (viz podtitul) nebo mýtech, ale to nikoli v jejich původním, skutečném, ale 
přeneseném, publicistickém smyslu, např. předbolševické modely, bolševické romány, stalinistický román, bohotvorba, modely rituálního obětování, poválečný stalinismus, Chruščovova léta, próza po Chruščovovi aj. Název díla neodpovídá jeho obsahu, nebot se nic podstatného nedovídáme o románu jako uměleckém žánru; nerozlišují se díla novelistická a románová, nebere se v úvahu tradice ruského románu apod. Terminologická nepřesnost se týká také označení sovětský román, nebot’ ten zahrnuje i romány neruské, např. významné vrstvy literatury ukrajinské, běloruské, gruzínské, arménské, estonské, kazašské, dokonce čukčské apod. Necitlivý vztah k tzv. sovětskému mnohonárodnímu celku, který dobově a úspěšně zprostředkovával časopis Družba narodov ruskými překlady, nebot’ tu skutečně - nehledě na vlastní literární tradice a vlastní mezinárodní vazby jednotlivých areálů (Ukrajina, Pobaltí, Kavkaz, stř̌ední Asie) - vznikal nadnárodní kontext, je slabou stránkou knihy - a to zdaleka nikoli jedinou. Periodizace literatury, která je těžkým problémem pro každého historika literatury a je hierarchizovanou strukturou řady kritérií, je tu „odbyta“ politickými „nálepkami“ (labels), jež v podstatě jen velmi málo vypovídají o literatuře a jejím vývoji a složitých peripetiích jejího vývoje. Taková kniha je užitečná pro ty, kteří o ruské sovětské literatuře vědí jen málo nebo nic, a nemohou si tudíž vytvořit vlastní názor. Výklad je naplněn materiálem, názvy děl a jmény autorů, trochu bez ladu a skladu, východiska a cíle jsou jasné a jednoznačné, složitostmi se autorka příliš nezatěžuje. Celé drama tzv. sovětské literatury se tu redukuje na prŕkazy strany a ideologické koncepty, živí autoři se svými konflikty a pochybnostmi se kamsi vytratili. Že to bylo složité, je zřejmé: ukazují to i osudy a postoje autorů uštvaných sovětskými úřady a médii a vytlačovaných na okraj, ale přesto respektovaných, jakým byl např. Boris Pasternak. Čtenáři mohou nabýt dojmu, že po přečtení knihy se stávají znalci, i když se tu často prodíráme pouhými „obsahy“ klíčových děl, jejichž výklad není ničím podstatným komplikován. Základním postupem je tu přesně to, čím se vyznačuje úspěšný novinář- ský článek: razantnost a jednoznačnost soudů, „označkování“ a začlenění do skupin. Některé pojmy jsou v našem povědomí jen stěží komunikovatelné: např́íklad tu pod hlavičkou „náznaky metafyzického hledání“ (s. 291) najdeme něco, co jen málo odpovídá naší představě metafyziky.

Autorka prochází vývojem tzv. sovětského románu jako realizací ideologických tezí, sbližování nebo odklonů od nich. Románová tradice tu je pouze v náznaku a jak je anglosaském světě zvykem, pozornost se soustředí na několik typových titulů, jiné jsou jen zmíněny. Od prehistorie socialistického realismu před rokem 1932 se dostáváme k jeho vývoji pozdějšímu, kde autorka využívá módních nálepek, antinomií a tezí, jež však nejsou hlubinně poetologicky (jako by taková disciplína ani neexistovala) osvětleny (stroj a zahrada, pastorále, novoplatónské rysy epistemologie vrcholného stalinismu apod.), které mohou být pro někoho přitažlivé a připadat mu jako objevné, ale neobsahují nic nového. Snad jen téma př́rody v Mladé gardě - také nenové - nebo „malá“ a „velká“ rodina, poněkud i vesnická próza - snesou přísnější měřítko.

$\mathrm{V}$ padesátých letech minulého století bylo u nás obtížné psát o literatuře bez ideologického „lešení“; od šedesátých let již to bylo možné a do značné míry a s jistou dovedností i za tzv. normalizace, když jsme se soustředili na text, v podstatě pracovali více či méně skrytou strukturní metodou, zabývali se poetikou nebo komparatistikou, jinak řečeno odkazovali jakobsonovsky na „literárnost“ a vyhýbali se př́imočarým sociologickým charakteristikám a krátkým ideologickým spojením. To platí dodnes, i když lze již mnohem více: východiskem k politickému uchopení a traktování krásné literatury musí být literatura jako esteticky relevantní artefakt, nikoli jako soubor „obsahů“ a informací, tedy toho, co autorka sofistikovaně nazývá epistemologií, což je zvykový termín užívaný v anglosaském světě a postupně skrze analytickou filozofii nediferencovaně vnucovaný i jinam, jenž bychom mohli také označit jako gnoseologii nebo noetiku. Zatím na druhé straně Atlantiku se často pěstovala př́ímočará sociologie a politologie literatury, nezřídka takřka marxistická svým 
„používáním“ literatury, někdy s opačným hodnotícím znaménkem. $\mathrm{K}$ tomuto druhu tzv. literární vědy (literary criticism) patř́i i posuzovaná kniha: postupy, jež jsme kdysi právem odsouvali stranou kvưli jejich schematičnosti a později se k nim vraceli jen opatrně, spíše k širším sociologickým konceptům spojovaným i se zázemím estetiky literárního artefaktu, v USA přežívají, jistě také proto, že je to žádoucí a také proto, že tu širší veřejnost (stejně jako u nás) - přes dnešní technologie - o ruské nebo ruské sovětské literatuře mnoho neví. Vinou známých okolností je tedy tato kniha určena především nejmladší české generaci rusistů, která záměrně není „zatížena“ českými slavistickými a rusistickými tradicemi a obecně českou znalostí Ruska a ruského světa. Schematické „nálepky“, nahuštěné tituly děl a jména autorů, převyprávění „obsahů“, tedy syžetů, a stručná „one-dimensional“ charakteristika, jsou v této knize obecněji platnou metodou. Oproti podceňování síly tzv. socialistického realismu, jež se vidí u nás, je tu patrné jeho přeceňování jako „hlavni konstitutivni sily“ (s. 351). ${ }^{1}$

Dával bych přednost nahlížet tyto problémy stř́zlivěji jako přirozený běh věcí: socialistický realismus byl kanonizován politicky, ale fakticky vycházel z existujících proudů literatury, jež v Rusku byla a nejde jen o Matku Maxima Gorkého nebo z předchůdců Co délat? N. G. Černyševského. To by autorka musela znát mnohem více než to, co nám demonstruje, a musela by naplnit svoji profesorskou titulaturu a přitom vše zkoumat jemnějšími nástroji estetické, nikoli jen politické analýzy. Jako profesorka srovnávací literatury a slovanských jazyků a literatur by např́klad mohla ukázat na širší než jen ruské/ sovětské souvislosti: u nás vznikla v díle Bedřicha Václavka samostatná česká koncepce socialistického realismu, podstatně odlišná od oficiální sovětské třicátých let 20 . století, navíc zde vznikla umělecká románová díla, která jsou tomuto smě-

1 Viz naši studii Socialistický realismus v české literatuře: tř̀ generace. In: BraSlav 2. Zborník z medzinárodnej slavistickej konferencie, konanej na Filozofickej fakulte Univerzity Komenského v Bratislave dňa 13. a 14. novembra 2003. Bratislava: UK, 2004, s. 280-288. ru vlastní a jsou esteticky kvalitní (M. Majerová, I. Olbracht, V. Vančura aj., nemluvě o české poezii té doby, jež má světový význam). Ale v českém meziválečném prostředí byl jen jedním z možných směrů, byt nikoli zanedbatelným. Lze to formulovat i tak, že šlo o boj uvnitř literatury mezi jejím přirozeným vývojem a dogmatickou normou, jak nám jej, možná ne zcela přesně, demonstruje M. Zahrádka. ${ }^{2}$

Čím více se autorka blíží současnosti, tím je její charakteristika literárních děl schematičtější a publicističtější, zejména v tzv. přílohách A a B, v oddílech o výrobním (asi bychom spíše řekli budovatelském) románu, v němž jsou dedukovány úkoly, jež spisovatel stanoví pro svého hrdinu. To se týká i konce socialistického realismu - rozbory děl z tohoto období (sedmdesátá až devadesátá léta 20. století) často nesnesou přísnější odborná měřítka (Ajtmatov, Bondarev), je tu velmi malý a necitlivý pohled na složitosti ruského literárního a politického vývoje, na jazyk, který jej vyjadřuje, v podstatě ke každé charakteristice lze mít připomínky. Je zřejmé, že autorka zná jen některá díla a nemá přesnější představu o uměleckém, lidském a uměleckém vývoji jednotlivých autorů (Č. Ajtmatov, J. Bondarev). Zůstává otázka, co poměrně rozsáhlá kniha vlastně představuje: zdali přehled syžetů ruské literatury sovětského období, nebo politické komentáře k ruskému literárnímu vývoji, nebo ještě něco jiného.

Zcela stranou ponechávám již zmíněný nenaplněný komparativní potenciál daný autorčiným širokým oborem na Yaleově univerzitě (z něho neukázala v podstatě nic, zkreslené pojetí sovětského románu jako socialistickorealistického, jímž přestává být jakoby na pokyn shora několika články, (mj. slavný článek Viktora Jerofejeva Поминки по советской литературе / Pohřební loučení se sovětskou literaturou z roku 1990, jenž jen konstatoval již dlouho existující stav) není př́liš začleněn do románu jako literárního žánru; chybí tu silněji přítomná teorie románu.

2 ZAHRÁDKA, Miroslav: Dogmata a živý literární proces. Jak vznikala úzká forma socialistického realismu a jak s ni ruská literatura bojovala. Olomouc: Miroslav Zahrádka, 1992. 
Horší je, že autorka, původem Australanka, jež prošla řadou amerických univerzit, známá jako tendující k marxismu, pokud ne přímo marxistka, tu neprojevila detailnější a kompetentní znalost ruského politického myšlení, nejen teorie literatury a románu. Sama se zabývá kromě politické reflexe literatury také divadlem a filmem, zatímco mezi jejími pracemi není nic, co by odpovídalo jejímu jmenovacímu oboru. Abychom však byli spravedliví, tak je tomu i jinde: existují univerzitní profesoři několika národních literatur, včetně ruské (a také české a polské), kteří rusky a polsky nečtou a nepíšou a nenapsali o ruské literatuře ani řádku. Takže si představte: např. o výsledcích státnic studentů ruštiny nebo polštiny může rozhodovat profesor, jenž o těchto oborech nemá ani ponětí. Kompetentní akademičtí činitelé často tvrdí, že se musíme učit od amerických slavistů: souhlasím s tím, že se musíme učit od kohokoliv, kdo má výsledky, na něco přišel, je kompetentní, vzdělaný a podnětný - at je odkudkoliv. Otázka je, zdali právě tato kniha je dobrým př́íladem.
Přesto nepovažuji její překlad a vydání za omyl nebo za zbytečné. V situaci drsné ostrakizace různohlasí české rusistiky, je tato kniha dokladem toho, že takové přístupy k literatuře žijí a mohou být z mnoha hledisek i poučné. Našim mladým poskytne informace, jichž se jim také vlivem nedostatečné četby a estetického školení a ignorance ( $\mathrm{k}$ níž jsou často vedeni) toho, co za dvě století vyprodukovala česká rusistika úpornou prací a často proti proudu ve všech obdobích, nedostává. Vše je tu nahromaděno, jsou tu poutavé příběhy, tedy převyprávění „obsahů“, jež si studenti tak rádi vzájemně sdělují, což někomu může nahradit autentický čtenářský zážitek (a je to pohodlné) a sumu informací, kterou mohou poslat dál. Současně vidíme, jak si počíná jeden z proudů současné americké rusistiky. Ani to není málo. Překlad se zdá být velmi dobrý, překladatel (roč. 1979) má podobný odborný rozsah jako autorka, zabývá se také marxismem a socialistickým realismem, jak hluboce zná ruskou literaturu, nevím, ale nemyslím si, že by tu došlo k nějakému podstatnému zkreslení. 